\title{
The Research of Low-Carbon Economy Assessment Chen-Ling $\mathrm{SHI}^{1, \mathrm{a}}$, Hai-Liang $\mathrm{MA}^{2, \mathrm{~b}}$, Ze TIAN ${ }^{3, \mathrm{c}}$ \\ Low-Carbon Economy Institution of Hohai University, China \\ a1029858675@qq.com, bmahlpaper@163.com, ${ }^{\mathrm{c}}$ tianz@hhuc.edu.cn
}

Keywords: Low-carbon Economy, Index System, Carbon Cycle, Carbon Dioxide.

\begin{abstract}
Recently, greenhouse effect caused by greenhouse gas emissions is becoming an increasingly heated topic. Developing a low-carbon economy is becoming a trend both abroad and at home. China is a main carbon emission country as well as the largest developing country. It is important to take prompt actions in this green campaign. This paper builds a low-carbon economy index system based on the reaches of low-carbon economy, which can be served as the theoretical support for developing a low-carbon society in our country.
\end{abstract}

\section{Introduction}

Currently, the emission of greenhouse gases (mainly carbon dioxide) has caused greenhouse effect, which arouses wide attention of the global society. Especially with the agreement of the "Bali roadmap" and the deepening of international action of dealing with global climate change, low-carbon economy has become one of the focuses in the global society. As a main carbon emission country and the largest developing country, China should try to explore a road of lowcarbon development, so as to reach the balance and harmony between social economic development and environmental protection. Therefore, our country needs to develop low-carbon economy, both to ensure the economic development, and to protect the environment, thus achieving a win-win situation of economic development and environmental protection.

\section{Theoretical Basis of Building Low-carbon Economy Index System}

The production, use and consumption of energy in a region can clearly reflect the current situation of local low carbon economic development. In general, the larger proportion of clean energy in energy structure, the better use of carbon in fossil energy, the more perfect of disposal mechanism of carbon waste, the better development of low carbon economy. Therefore, the carbon conversion through the process of production and living can be simplified into the model shown in figure 1. Thus, in order to achieve a low-carbon economy, we can mainly control the following four aspects.

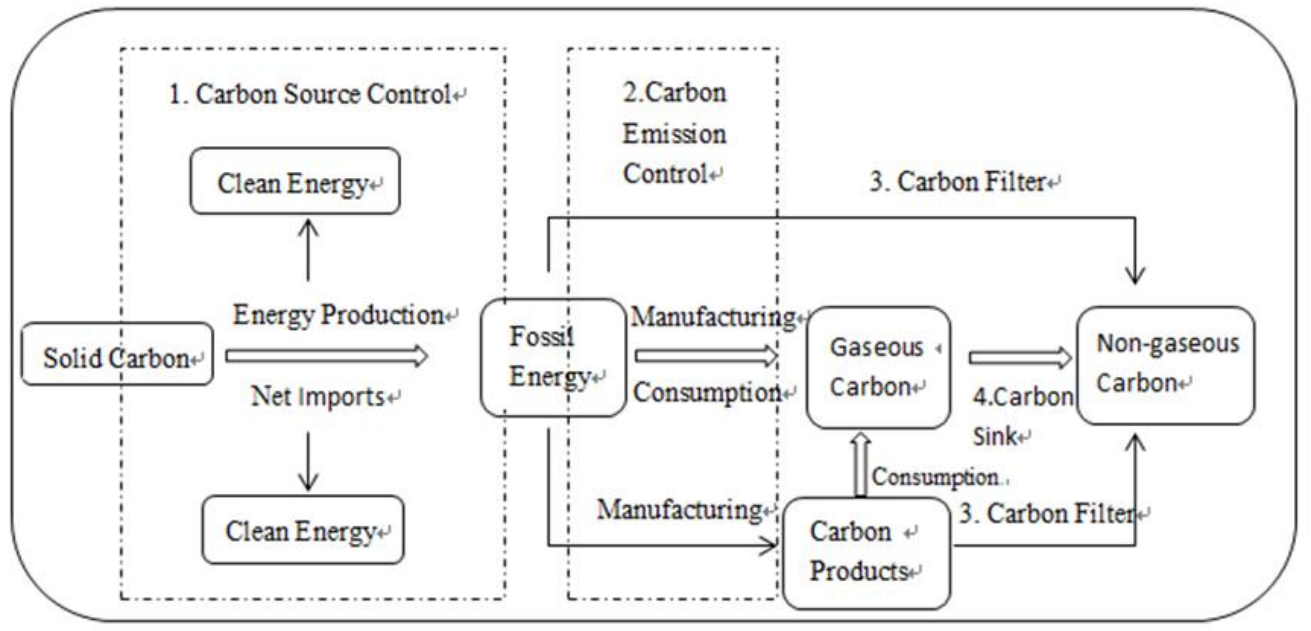

Fig. 1 Model of Carbon Cycle 


\section{Carbon Source Control Point}

Carbon source control belongs to pre-control. Based on the basis of the previous carbon cycle model, the measurement index of low-carbon economy can be considered from the following several aspects: (1) energy structure. The root cause of excessive carbon emission is the use of fossil energy in energy structure, and what low-carbon economy advocates is a kind of economic development mode mainly aims to reduce energy consumption, pollution, emissions and carbon content in energy using. (2) energy cooperation and import and export trade. Low-carbon economy is becoming a trend of world development. The prosperity of carbon emission permits and its derivatives' trading as well as the extensive cooperation and development of energy technology mean that low- carbon economy development shows a good momentum and huge development potential in the future.

\section{Carbon Emission Control Point}

Now, under the situation that fossil energy is still the predominance in energy structure, carbon emissions can be used as a measure index of regional economic development level. Adopting the low-carbon economy development pattern will be obligations for countries and regions with large carbon emissions. Therefore, carbon emissions indexes can be used to well clarify different areas' shared responsibilities of energy saving and emission reduction, and is an important mandatory target in low-carbon economy development.

\section{Carbon Filter Control Point}

The development model of low-carbon economy can optimize energy structure, reduce energy use, increase the efficiency of energy utilization, create low carbon products and change people's concept of production, living and consumption. Index found out on the basis of carbon filter control point can comprehensively reflect different regions' potential of reducing energy consumption, emission and pollution under the condition of not sacrificing economic benefit and efficiency.

\section{Carbon Sink Control Point}

Photosynthetic needs to absorb carbon dioxide from the air and carbon sink makes use of this process to eliminate and reduce greenhouse gases in the air and restore the eco-balance. Things like enlarging the area of afforestation and increasing urban green rate all belong to carbon sink control. Commonly used indexes include forest coverage rate, city green coverage rate, etc.

\section{Principles of Setting Low-carbon Economy Evaluation Index System}

Evaluation index system is composed of several interrelated statistical indexes. According to the evaluation index, we can analyse and clarify the interdependence and mutual restriction relationship between each research object from different levels, thus reflecting the whole situation of the research object from different angles. Therefore, scientific and reasonable evaluation is not only the prerequisite and guarantee for the accurate evaluation of research objects, but also an important channel to help guide the correct development direction. Low-carbon environmental protection evaluation index system emphasizes the mutual coordination and sustainable development of economic development, technological innovation, social progress and environmental optimization. When establishing the concrete evaluation index, we should follow the following principles:

1. Scientific Principle

As the fundamental factor of evaluation index system, scientificity meets the requirements of objective law of low-carbon economy development and environmental protection. Understanding and acquiring low-carbon environmental protection accurately and systematically can not only reflect the essential characteristics of low-carbon environmental protection, but also emphasize the 
feasible goal of low-carbon environmental protection, which ultimately serve for making the right development decision.

2. Systemic Principle

Social and economic development environment is a multi-level and complex system, which consisted of several interconnected subsystems, including economic subsystem, environment subsystem, social subsystem, resources subsystem, etc. Every subsystem is not independent.

3. Feasibility Principle

The purpose of building evaluation index is to effectively evaluate items concerning low-carbon economy, thus fully reflecting the current situation of low-carbon economy development. Therefore, the selection of indexes must be based on physical situation and try to select some typical and practical indexes.

4. Stability and Dynamic Principle

In order to make comparison and evaluation easily and accurately grasp the development present situation and predict future trends, selected indexes should be stabile within a certain period. As economic development, environmental change and technological advancements are dynamic rather than static; the indexes should make necessary adjustments based on the development of society, economy and technology.

5. Political Principle

Environmental protection is a global issue and no country can keep out of it. Therefore, making evaluations should not only synthesize domestic situations, but also take international situation into consideration. Thus, national policies and relevant international conventions should be served as instructions when designing low-carbon environmental protection evaluation indexes.

\section{Design of Low-carbon Environmental Protection Evaluation Indexes}

Low-carbon environmental protection is a multi-level and complex system composed of two parts: low-carbon economy development and environment protection, including economy, science and technology, resources, society and environment, etc. Comprehensively reflect the current situation of low-carbon environmental protection and its evaluation demands analysis from different angles and levels by using various indexes. Based on the theoretical analysis above, this part constructs an index framework which includes first grade indexes, second grade indexes and third grade indexes, and set up several in each level indexes to achieve comprehensive evaluation of low carbon environmental protection (see table 1).

Tab. 1 Low-carbon Environmental Protection Evaluation Indexes

\begin{tabular}{|c|c|c|c|c|}
\hline $\begin{array}{c}\text { First } \\
\text { Grade Index }\end{array}$ & $\begin{array}{c}\text { Second Grade } \\
\text { Index }\end{array}$ & Third Grade Index & Unit & $\begin{array}{c}\text { Index } \\
\text { Property }\end{array}$ \\
\hline \multirow{13}{*}{$\begin{array}{c}\text { Level } \\
\text { of } \\
\text { Low-Carbon } \\
\text { Environ- } \\
\text { mental } \\
\text { Protection }\end{array}$} & \multirow{3}{*}{$\begin{array}{c}\text { Economic } \\
\text { Development } \\
\text { Index E1 }\end{array}$} & Per Capital GDP (E11) & 10,000 yuan/person & Target Type \\
\hline & & GDP Growth (E12) & Hundred million & Target Type \\
\hline & & Fixed-Asset Investment (E13) & $\%$ & Target Type \\
\hline & \multirow{6}{*}{$\begin{array}{l}\text { Low-carbon } \\
\text { (Technology) } \\
\text { Development } \\
\text { Index E2 }\end{array}$} & $\begin{array}{l}\text { Energy Consumption Elasticity } \\
\text { Coefficient(E21) }\end{array}$ & $\%$ & $\begin{array}{l}\text { Restrained } \\
\text { Type }\end{array}$ \\
\hline & & $\begin{array}{l}\text { Energy Conversion Efficiency of Processing } \\
\text { (E22) }\end{array}$ & $\begin{array}{l}\text { Tons of standard } \\
\text { coal/ } 10,000 \text { yuan }\end{array}$ & Target Type \\
\hline & & $\begin{array}{l}\text { Energy Consumption Per RMB 10,000 of } \\
\text { GDP (E23) }\end{array}$ & $\begin{array}{c}\text { Tons/ } \\
10,000 \text { yuan }\end{array}$ & $\begin{array}{l}\text { Restrained } \\
\text { Type }\end{array}$ \\
\hline & & Carbon Emission Intensity (E24) & $\%$ & $\begin{array}{l}\text { Restrained } \\
\text { Type }\end{array}$ \\
\hline & & Proportion of Clean Energy (E25) & $\%$ & Target Type \\
\hline & & Proportion of Tertiary Industry in GDP (E26) & $\%$ & Target Type \\
\hline & \multirow{4}{*}{$\begin{array}{c}\text { Social } \\
\text { Development } \\
\text { Index E3 }\end{array}$} & Growth Rate of Population (E31) & $\%$ & $\begin{array}{l}\text { Restrained } \\
\text { Type }\end{array}$ \\
\hline & & Final Consumption Rate (E32) & $\%$ & Target Type \\
\hline & & Urban Rubbish Disposal Rate (E33) & Yuan & Target Type \\
\hline & & Per Capita Health Expenditure (E34) & $\%$ & Target Type \\
\hline
\end{tabular}




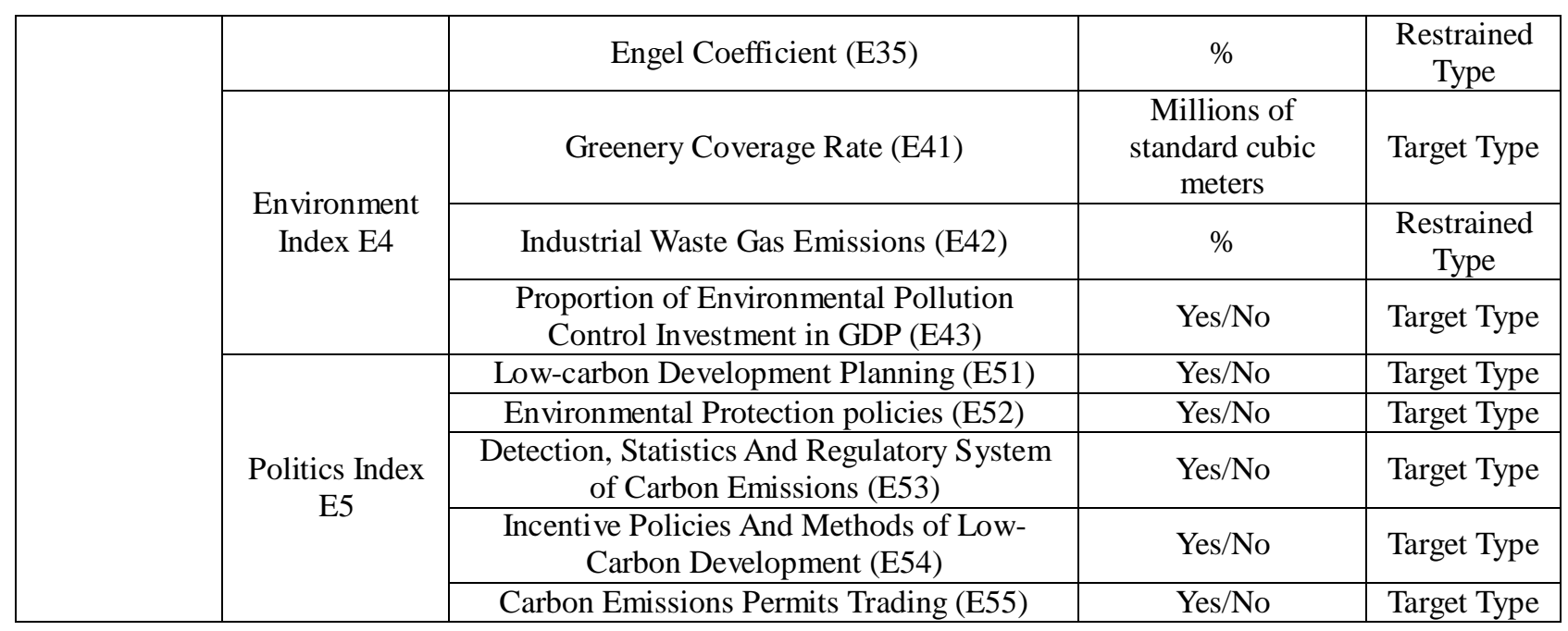

\section{Conclusion}

At present, the low-carbon economy has become a common concern and research hot spot issue. But there is a lack of research on low-carbon economy at home, especially on low-carbon economy evaluation index system and methods. Based on the theoretical basis of low-carbon economy and setting principles of index design, this paper constructs a low-carbon economy index system, so as to provide theory support for the construction of low-carbon society in our country.

\section{Acknowledgements}

Supported By the Fundamental Research Fund for the Central University of China (2013B19414, 2013B09414)

\section{References}

[1]Lv Xuedu, Wang Yanping, Huang Chao, and Sun Ji. Research of Low-carbon Economy Evaluation Methods Index System. China Population, Resources and Environment, July 2013.

[2]Xiao Cuixian, Tang Shanmao. Research of Urban Low-carbon Economy Evaluation Index System. Ecological Economy, January 2011.

[3]Zhang Wenting. Research of Low-carbon Economy Comprehensive Evaluation Index System Of Central Economic Cites Around Yangtze River. Wuhan University of Technology, December 2013.

[4]Wu Xue, Chen Jin, Li Shuang. Construction of Low-carbon Economy Evaluation Index System. Enterprise Economy, June 2012.

[5]Qi Ming. Low-carbon Economy Evaluation Index System and Evaluation Research of Our Country. Shandong Normal University, April 2011.

[6]Feng Bimei. Research of Low-carbon Economy Evaluation Index System of Hubei Province. China Population, Resources and Environment,March 2011.

[7]Yang Zhen. Comprehensive Evaluation of China Low-carbon Economy Development. Liaoning University, April 2013. 